\title{
The Taliban Conundrum
}

\author{
Mudassir Fatah \\ Research Scholar, Department of Political Science, Jamia Millia Islamia, New Delhi-110025
}

\begin{abstract}
National interests do guide the foreign policy of a nation. A state can go to any extent for fulfilling the same. Same had been reflected in the proxy wars played in Afghanistan. It is these national interests of some states which are responsible for the rise of the Taliban movement. Although there are some internal factors who also played a crucial role while giving birth to the Taliban movement, but these internal circumstances were created so to be the part of the conflict which eventually gave rise to the Taliban movement. The cold war power politics played in the poor and a weak nation like Afghanistan resulted in such a force which is still haunting the millions in the world.
\end{abstract}

Keywords: - Afghanistan, Civil War, Peace, Power Politics, Taliban.

\section{INTRODUCTION}

Taliban is the plural of 'Talib', which has its origin from Arabic. The literal meaning of Talib is seeking something for one's own self. The word Talib has been derived from the word 'Talab' which means desire. The word Taliban, in Pushto, generally denotes, students studying in Deeni Madaris (religious schools). ${ }^{1}$ These Deeni Madaris were (mostly) Deobandi schools in Pakistan.

\section{RISE OF THE TALIBAN MOVEMENT-INTERNAL FACTORS}

After the Soviet departure, the factor which united all the Mujahedeen groups against the common enemy, no longer existed, which resulted into chaos, looting and finally civil war. The immediate cause of the rise of the Taliban was the lawlessness after the soviet withdrawal. According to Masoom Afghani the struggle for power between Hekmatyar and Burhanuddin Rabbani killed around 50,000 people. ${ }^{2}$ With this destruction of civil war, people lost their faith in their leaders. With the passage of time the students of deeni madaris across Af-Pak border took a serious note of these problems. Earlier, both US and USSR agreed to put an end on the aid to the respective favourites in Afghanistan by January 1, 1992. With the expiry of Soviet support to Dr. Mohammad Najibullah, the effects on his government were felt immediately. Now Najibullah was not able to sustain the attacks of Mujahedeen from every side for so long, but he managed to be in power till 1992. The Mujahedeen groups of Ahmed Shah Massoud, Gulbuddin Hekmatyar, Abdul Rasul Sayyaf, Abdul Ali Mazari and others, all started marching towards the Kabul from their respective dominant areas. ${ }^{3}$ Mujahedeen entered Mazari-Sharief on March 18, 1992, that too without fight. On the same day out of fear, Najibullah announced his wish to quit on the condition that a neutral government could be installed. ${ }^{4}$ Finally, the attacks of the different Mujahedeen factions led Kabul regime to surrender in a month.

Pakistan while watching the whole game was very eager to be part of any future reconciliation in order to continue its dominance in Afghanistan. To realise this goal, Prime Minister of Pakistan, Mr. Nawaz Sharief, persuaded most of the Afghan Mujahedeen leaders to sign an accord, in which he finally succeeded by signing Peshawar Accord on April 24, 1992. But, unfortunately, Gulbuddin Hekmatyar, who was an important stakeholder at that time in Afghan politics did not attend this meeting. ${ }^{5}$ Although, Peshawar Accord was signed with the consent of most of the Mujahedeen leaders, peace was never a reality. After the common enemy (Communist regime) was over, old enmities between the different ethnic groups once again started dominating the scene with ethnic (enemy) background. In the spring of 1993, Pakistan, Saudi Arabia and Iran increased their pressure for solving regional problems. Under this pressure all the parties reached an agreement on March 7, 1993 and signed an accord known as 'The Islamabad Declaration: Afghan Peace Accord'. Ahmed Shah Massoud, who was given the position of defence minister under the Peshawar Accord resigned now under a new

\footnotetext{
${ }^{1}$ Kamal Matinuddin, The Taliban Phenomenon: Afghanistan 1994-1997 (New Delhi: Lancer Publishers, 2000 ), p. 12.

2 Ibid., p. 22.

${ }^{3}$ Ibid., p. 7.

${ }^{4}$ Gilles Dorronsoro, Revolution Unending, Afghanistan: 1979 to the present (London: Hurst \& Company, 2005), pp. 237-238.

${ }^{5}$ Matinuddin, The Taliban Phenomenon, pp. 7-8.

DOI: 10.9790/0837-2201022126 www.iosrjournals.org $\quad$ 21|Page
}


accord, ratified on May 18, Rabbani was officially installed as a defence minister, because Hekmatyar and Massoud were arch rivals and they couldn't have continued on the same platform. ${ }^{6}$

This accord was again aimed at bringing peace and putting an end to the armed hostilities. President Burhanuddin Rabbani was to continue with his position for next eighteen months and Gulbuddin Hekmatyar was given the post of Prime Minister. Ceasefire between all Mujahedeen groups was to come into force with immediate effect. Election Commission was to be constituted and a national army was to be formed too. Unfortunately, all the efforts (Peshawar Accord, Islamabad declaration, Organisation of Islamic Cooperation (OIC) as well as UN) failed to yield any peace. ${ }^{7}$

When all the efforts failed, Mujahedeen factions once again started fighting each other, thus resulted in civil war, and peace never came to Afghanistan. Unfortunately, all the factions were highly distrustful towards each other, even after belonging to same nation and to same religion. Every group wanted to have full access and control of the central government. Ethnic enmity again dominated the scene, Muslims started killing fellow Muslims, for the lust of power. All religious values came to an end. The Soviet withdrawal had generated optimism for peace, but unfortunately all the militant factions with high distrust, started barbaric killing of other groups. All the Mujahedeen factions were fully armed by the US and Pakistan during Soviet occupation. The weapons which were used to kill Soviets, were now being used to kill fellow citizens of Afghanistan. Destruction, chaos and confusion again rang the bell of the people of Afghanistan. Now, civil war was going on at its peak, with everyone's hand on the throat of every fellow citizen. During the civil war from 1992-1994, 45000 Afghans died. Burhanuddin Rabbani and Hekmatyar were now involved in a severe fight for power. ${ }^{8}$

The frustration of the civil war, lead Talib to seriously think about the situation of Afghanistan. All Mujahedeen factions were looking for the solution of the same problem, but yielded nothing. This lead these madrasa students (later on Taliban) chalk out the strategy and an agenda with some declared aims- restore peace, disarm the population, enforce Sharia law and defend the integrity and Islamic character of Afghanistan. To them (Taliban) it was a movement for cleaning society without an eye on power. ${ }^{9}$

Overall situation worsened with every passing day, and all the Mujahedeen factions continued their struggle for power. These reasons actually paved the way for the rise of the Taliban. Failure of the Mujahedeen in uniting the people of Afghanistan and in implementing the Islamic government, as well as reliance on the Western support were somehow directly responsible for the rise of the Taliban. If the official version of the Taliban is to be believed about their origin, then they trace it to a humble madrasa located in Singesar village of Kandahar province's district Maiwand, where Mullah Mohammad Omar and his thirty comrades decided to take arms in the summer of 1994, when there was arbitrary taxation, robbery and rape had become a norm on the highways. Movement grew from there out of anger on the Mujahedeen. ${ }^{10}$ To some, Taliban was born from among those refugees of Afghanistan staying in Pakistan. The Taliban as a student movement from the school's setup for Afghan refugees in Pakistan. Those schools mostly belonged to the Jamiat-e Ulema Islam, and they had close ties with the Benazir Bhutto government. ${ }^{11}$

Though the exact origin of the Taliban is still a mystery, but one thing is clear that the Taliban emerged from the youth among the refugees who were studying in deeni madaris in and around Quetta, Peshawar, Lahore and Gujrawala. ${ }^{12}$ Apart from Haji Bashar of Maiwand, who was commander in Hezb-i-Islami, it is believed that a close associate of Mullah Omar, Mullah Mohammad Rabbani with some of his companions paid a visit to President Rabbani and gained his support with financial backing too. President Rabbani intended to use the Taliban force against his arch rival Gulbuddin Hekmatyar. ${ }^{13}$

It was 1994, when Taliban for the first time came to limelight. ${ }^{14}$ The decreasing popularity of the Mujahedeen and the increasing mismanagement everywhere also contributed to the rise of the Taliban. The first opportunity fully exploited by the Taliban was freeing of the two teenage girls from the Mujahedeen, who were abducted, shaved and then raped repeatedly by the Mujahedeen at the checkpoint. These two girls belonged to the Kandahari village of Sang Hesar. One of the most important things to be noted here is the Mujahedeen commander who had abducted these girls was hanged from the barrel of the tank. ${ }^{15}$ Elsewhere, a boy was freed

\footnotetext{
${ }^{6}$ Dorronsoro, Revolution Unending, Afghanistan, p. 243

${ }^{7}$ Matinuddin, The Taliban Phenomenon, p. 8.

${ }^{8}$ Ibid., p. 10.

${ }^{9}$ Ahmed Rashid, Taliban: The Story of the Afghan Warlords (London: Pan Macmillan, 2001), pp. 22-23.

${ }^{10}$ Anthony Davis, "How the Taliban becomes a Military Force," in Fundamentalism Reborn? Afghanistan and the Taliban, ed. William Maley. (New York: New York University Press, 1998), p. 43.

${ }^{11}$ Daniel L. Byman, and Kenneth M. Pollack, Things Fall Apart: Containing the Spillover from an Iraqi Civil War (Washington D.C: Brookings, 2007), p. 104

${ }^{12}$ Matinuddin, The Taliban Phenomenon, pp. 21-22.

${ }^{13}$ Davis, "How the Taliban becomes a Military Force," p. 44.

${ }^{14}$ Naznin Qureishi, "Genesis of Taliban," in Challenges to Religions and Islam: A Study of Muslim Movements, Personalities Issues and Trends, ed. Hamid Naseem Rafiabadi (New Delhi: Sarup \& Sons, 2007), p. 582.

${ }^{15}$ Michael Griffin, Reaping the Whirlwind: Afghanistan, Al Qa ida and the Holy War (London: Pluto Press, 2003 ), p. 32.

DOI: 10.9790/0837-2201022126 www.iosrjournals.org 22 | Page
} 
by one of the Taliban squad, over whom two warlords were fighting with each other for the right to sodomize. ${ }^{16}$ After these two incidents, Mullah Mohammad Omar had emerged as a Robin Hood figure. To Ahmed Rashid, his image and prestige grew a lot most importantly because he didn't ask for rewards from those he helped, Omar only demanded the loyalty and following from those people as to set up an Islamic system. ${ }^{17}$

On October 12, 1994, Taliban was rewarded with a great success, that too in their initial years. Taliban divided its 200 cadres into three groups, crossed the border from Pakistan with the help of Pakistani army as they were supported by artillery fire by army from Pakistani side. The Taliban occupied the town of Spin Boldak, which constituted an important area of Hekmatyar. Apart from this success, it showed their strength as only one Talib died in the fighting. It also seized an arms depot containing large ammunitions. ${ }^{18}$ When Taliban got control of Spin Boldak, Hekmatyar credited their success to Pakistan, because same was done by him six years ago, ${ }^{19}$ while taking the control of the same town, so he immediately credited Taliban's success to them.

Ahmed Rashid believes that the failure and lapse of the radical Islamism, Sufism and traditionalism, created an "ideological vacuum", which was to be filled by the Taliban. ${ }^{20}$ Afghanistan, at this time was actually a failed state, failed in every respect, this failure of the system actually paved the way for the Taliban to come into limelight. If the Mujahedeen would have run the government smoothly, may be situation would have been something different.

Daniel P. Sullivan has given one of the finest explanations to the rise of the Taliban. To Sullivan, 'mobilization of a unique ideology' with the help of external support, played an important role in the rise of the Taliban. Sullivan further believes that disappointment, poor socio-economic conditions, ethnic divisions, a large cadre of disaffected young males etc. further paved the way for Taliban's entry. State failure is also believed to be a reason. External support, according to Sullivan fuelled the fire, so to spread with the fast speed. While defining the Tinder, the existing conditions are worth mentioning. The disappointment of the people played the role of Spark, as discussed by Sullivan, by using the J-Curve formula to prove his point. Mobilization of an ideology provided the oxygen that fed the fire (Taliban). The most important, in the whole game is 'fuel that spread the fire', i.e. the external support. With all this Taliban came into existence. ${ }^{21}$

The Taliban movement, emerged in the late 1994, as a messianic movement, consisting of a group of people from Islamic seminaries living in the refugee camps in Pakistan, to bring peace to Afghanistan. ${ }^{22}$ There is a wide difference for what the movement started and where it ended. Without having any inclination towards power in 1994, they ended up with full control over the government of the Afghanistan in 1996.

\section{EXTERNAL FACTORS-ROLE OF PAKISTAN}

According to Ahmed Rashid, the Taliban were born in Pakistani refugee camps, educated in Pakistani madrasas and learnt their fighting skill from Mujahedeen parties based in Pakistan. ${ }^{23}$ With the departure of the Soviets, Afghanistan was left at the mercy of the Mujahedeen. Trust deficit among the different Mujahedeen groups increased. The ongoing civil war also posed a challenge to the government of Pakistan, because they had been seriously involved in arming these Mujahedeen groups during Soviet occupation. This was a challenge as well as an opportunity in itself for Pakistan, a challenge in the form of increasing refugee influx from Afghanistan to Pakistan, disturbed neighbour and a place for Iran to get its share in the Afghan politics. It was an opportunity, as Pakistan was going to have a lion's share as well as 'Strategic Depth' in the future politics of Afghanistan. Pakistan was seriously looking for the future dominance in Afghanistan, but the fighting of the Mujahedeen with each other flooded the aspirations of the government of Pakistan for some time. After serious thinking and curious watching, government of Pakistan noticed the early success of a new group, dominated by the Pashtuns. Government of Pakistan extended their support to this group through Inter-Services Intelligence (ISI). Pakistan started financial as well as military aid to the Taliban, military training was also the part of the plan. With all the support and strong backing, Taliban started mobilizing its forces and war against all the factions of the Mujahedeen and warlords subsequently started gaining control of different cities in Afghanistan. ISI's support to the Taliban was for securing the route between Quetta and Kandahar. The reason for this support was clear, Taliban had freed Pakistani vehicles that had been held hostage by some local warlords and also opened the route to Kandahar for these vehicles. ${ }^{24}$ Anarchy inside Afghanistan and the Pakistan's initiatives

\footnotetext{
${ }^{16}$ Michael Rubin, "Who is Responsible for the Taliban," Middle East Review of International Affairs 6, no. 1 (2002): pp. 6-7.

${ }^{17}$ Rashid, Taliban: The Story of the Afghan Warlords, p. 25.

${ }^{18}$ Davis, "How the Taliban becomes a Military Force," pp. 45-46.

${ }^{19}$ Abdul Kader H. Sino, Organisations at War in Afghanistan and Beyond (United States of America: Cornell University Press, 2008), p. 226.

${ }^{20}$ Rashid, Taliban: The Story of the Afghan Warlords, p. 88.

${ }^{21}$ Daniel P. Sullivan, “Tinder Spark, Oxygen, and Fuel: The Mysterious Rise of the Taliban,” Journal of Peace Research 44, no. 1 (Jan. 2007): pp. 93-108.

${ }^{22}$ Ahmed Rashid, "The Taliban: Exporting Extremism," Foreign Affairs, 78, no. 6(1999): pp. 22-35.

${ }^{23}$ Rashid, Taliban: The Story of the Afghan Warlords, p. 185.

${ }^{24}$ Dorronsoro, Revolution Unending, Afghanistan, p. 245.

DOI: $10.9790 / 0837-2201022126$

wWw.iosrjournals.org 23 | Page
} 
are considered as two major reasons for the rise of the Taliban. ${ }^{25}$ Pakistan worked hard along with their Saudi sympathisers in removing the barriers in the way of the Taliban movement. Surrenders of many warlords, including head of Jalalabad Shura, Haji Abdul Qadeer, were arranged. Pakistan also influenced and prompted various Afghan commanders to join the Taliban. Apart from the military and economic help of the Taliban, helping the Taliban on the ground was also the strategy of Pakistan to enable the Taliban capture power in Afghanistan. ${ }^{26}$ In October, 1993, Benazir Bhutto was elected as Prime Minister of Pakistan for second term. She took the reins of the country from the military. Nasirullah Babar and Benazir Bhutto took the strong note and were not in favour of any kind of soft approach towards Afghanistan. Babar, who had been earlier close to Zulfiqar Ali Bhutto too was in favour of promoting the trade route to Central Asia. For this purpose, the answer lay in the Taliban. ${ }^{27}$ Taliban was never an indigenous movement of Afghans completely, rather the brainchild of Pakistan's ISI to a large extent. It became clear when Pakistan choose a former Mujahid, Mullah Mohammad Omar, as its spiritual leader and guide. It is widely believed in some quarters that, Mohammad Omar was the choice of Nasirullah Babar, the interior minister of Benazir Bhutto government. ${ }^{28}$ Babar had earlier organised covert guerrilla training for Hekmatyar and Masood during 1970's when they had fled to Pakistan. ${ }^{29}$ One of the important reasons why Pakistan needed pro-Pakistani and friendly government in Afghanistan was the trade to be done with the newly independent Muslim nations of Central Asia, who were disintegrated from USSR. Pakistan was looking forward for exporting the goods to these nations but Afghanistan was in the way as a barrier to this dream. Civil war, lawlessness and loot were on its peak in Afghanistan. The route to Central Asian republics was through Kandahar and Herat. Benazir Bhutto thought that they should bypass Kabul and built roads and all other needed infrastructure through Pashtun areas. Bhutto made it clear that "if it could be done by bypassing local warlords" then ISI had no objection. ${ }^{30}$ Finally the dream of trade route came true, when in October 1994, a convoy carrying Pakistani textiles drove from Quetta to Turkmenistan. This was a trail for checking purpose. The convoy was blocked twenty miles outside of Kandahar, Babar waved the Taliban to free the Pakistani trucks, which they (Taliban) did very easily. ${ }^{31}$ Babar is believed to be the architect of the Taliban support structure. ${ }^{32} \mathrm{He}$ is further described as the 'godfather' of the Taliban as he in 1994, had recruited, trained and armed the madrasa students to provide protection of the Pakistan's convoy en route to Central Asian Republics through Afghanistan. The success of this group later received consent and sanction of the ISI and Maulana Fazlur Rahman. Then ISI seriously worked for the development of the Taliban into a 'credible ideological and fighting force'. ${ }^{33}$ With Taliban gaining ground on Afghan soil, Pakistan's loyalty got shifted in due course of time, from Hekmatyar to Taliban. ${ }^{34}$ It is believed that Nasirullah Khan Babar was the chief advocate of shifting their (Pakistan's) loyalty from Hekmatyar to Taliban. The main reason for this was freeing the Pakistani convoy from PDPA militia in Kandahar. ${ }^{35}$

In one of the delegation level meeting with ISI in Rawalpindi, members of the Taliban delegation urged ISI for withdrawing their support to all other Afghan leaders, Hekmatyar included. Qazi recalled that Taliban wanted "to hang all of them-all of them" one of the important demands of the Taliban on Pakistan was to export gasoline with an exception from trade rules, Qazi had agreed, with the demands of Taliban delegation. ${ }^{36}$ Mention may be made here, this was the first formal meeting between ISI and the Taliban. ${ }^{37}$ One of the officers of ISI, named as 'Colonel Imam', also played an important role in the rise of the Taliban, he also served as Pakistan's Consul-General in Herat, and he had earlier served as a trainee to Afghan Mujahedeen. ${ }^{38}$

It is widely believed that during the Taliban rule in Afghanistan, Pakistan took very good care of them by supplying military equipment's, military advisors, food and fuel and in addition thousands of students from madrasas were also sent to serve them. ${ }^{39}$ Even it was reported that Pakistan honoured the Taliban by

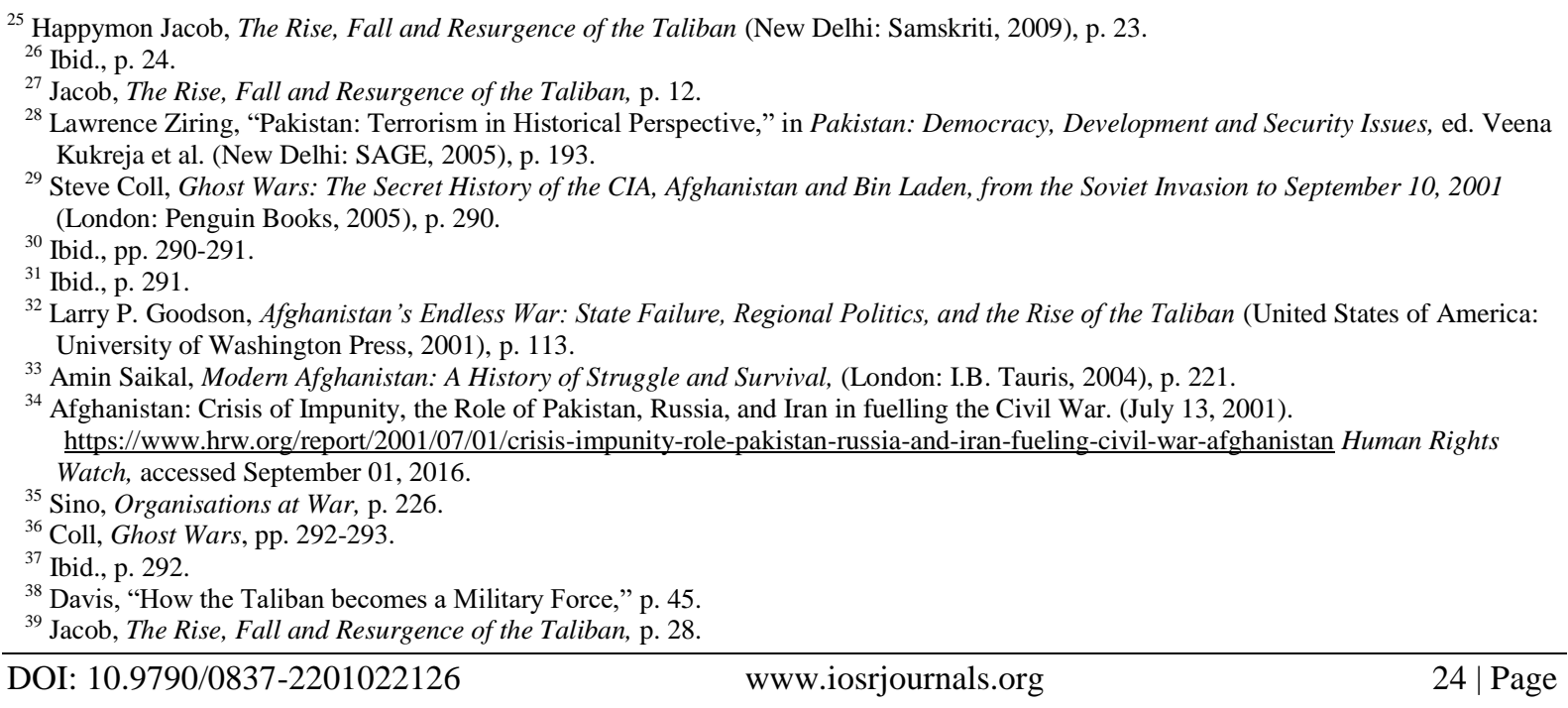


encouraging Pakistani to fight for them, and paid salaries to employees during the Taliban rule. In addition, tanks, and artillery were provided too. Taliban's air force and airports were also provided maintenance. ${ }^{40}$ According to Ahmed Rashid, the flow of aid was a legacy from the past. ${ }^{41}$ Pakistan support to the Taliban include, "weapons, ammunition, fuel, communication equipment, maintenance of armour and airplanes and transport for men and material". Pakistan in addition recruited the talib for the Taliban, thousands of Pakistani youth were recruited by ISI for filling the Taliban ranks. ${ }^{42}$

Not only Government of Pakistan, even some non-state actors of Pakistan played their role too in the development and the rise of the Taliban, worth mentioning are JUI, Lashkar-e-Toiba, Hizbul Mujahedeen, Harkatul Mujahedeen and Tehrik-e-Jihad. The students in the different madrasas were encouraged to join the Taliban whenever needed and on the special appeals of Mullah Mohammad Omar. In addition to the recruits, these organisations also provided monetary aid to the Taliban. ${ }^{43}$

Afghanistan was now the top priority in the second term of Benazir Bhutto's government (1993-96). Babar created an "Afghan trade Development Cell" within Interior Ministry, whose fundamental task was to promote the Taliban while having every kind of support from Pakistan. ${ }^{44}$ Pakistan's support to the Taliban can be best described in the words of Goodson, "As time passed, Pakistan's involvement with the Taliban, which came from various sectors of the Pakistani government and society, become so comprehensive that it became to drive Pakistan's policy toward Afghanistan. Pakistani support for the Taliban included direct and indirect military involvement, logistical support, recruitment, financial aid, and diplomatic recognition". ${ }^{45}$ The role of Pakistan is widely debated and it has been agreed that Pakistan was the principal creator of the movement of the Taliban. All the evidences have been found in favour of Pakistan's strong role in the rise of the Taliban. Pakistan had supported Taliban in every respect i.e. training, planning, financing, manpower and most importantly, diplomatically. Taliban reportedly received training in the military camps under the supervision of Pakistan's military, in madrasas, operating in North-West Frontier Province (NWFP) and Southern Afghanistan. ${ }^{46}$ To Gilles Dorronsoro, the emergence of the Taliban is, in itself, a by-product of the Pakistani policy towards Afghanistan. ${ }^{47}$

\section{ROLE OF THE UNITED STATES OF AMERICA}

Directly or indirectly, intentionally or unintentionally, US also supported the rise of the Taliban. US neither pressed upon Pakistan to stop fuelling Taliban, nor stopped Saudi Arabia for funding them. Initially the policy of US towards Taliban was friendly, it was because of two major reasons, countering Iran and their economic interests in Central Asian Republics. To counter Iran, US found a perfect match in Taliban. Rashid believes that, "the Clinton administration was clearly sympathetic to the Taliban, as they were in line with Washington's antiIran policy and were important for the success of any southern pipeline from Central Asia that would avoid Iran". ${ }^{48}$ Tehran accused Washington of funding the Taliban, so as to destabilise Iran, the charge refuted by the US. Raphel said to Rashid, 'we do not favour one factor over another nor do we give any group or individual support'. ${ }^{49}$ The foreign policy of all the countries is directed by its national interests. Until Taliban served the interests of the US, they did nothing against them (Taliban), if they were reluctant supporting the Taliban directly, they did it indirectly, because of their economic interests, which US felt are necessary in relation to Central Asian Republics, they played their role as the mute spectators. Going back to US covert operation during Soviet occupation of Afghanistan, it is open (secret) how much importance 'Operation Cyclone' was given. US provided every kind of support to Mujahedeen to fight Soviets. This support to Mujahedeen also contributed to the rise of the Taliban, of course very differently, indirectly, and in fact after a long time. According to Harrison" "The CIA made a historic mistake in encouraging Islamic groups from all over the world to come to Afghanistan". He was speaking in London at the Conference, in March 2000 on "Terrorism and Regional Security: Managing the Challenges in Asia". In his meetings with CIA, Harrison had warned CIA of creating a monster. He believed that, the creation of the Taliban had been "actively encouraged by the ISI and

\footnotetext{
${ }^{40}$ Rashid, Taliban: The Story of the Afghan Warlords, pp. 183-184.

41 Ibid.

${ }^{42}$ Goodson, Afghanistan's Endless War, p. 112

${ }^{43}$ Goodson, Afghanistan's Endless War, p. 113.

${ }^{44}$ Rashid, Taliban: The Story of the Afghan Warlords, p. 184.

${ }^{45}$ Goodson, Afghanistan's Endless War, p. 111.

${ }^{46}$ S. V. R. Nasr, "Islam, the State and the Rise of Sectarian militancy in Pakistan," in Pakistan: Nationalism without a Nation? ed. Christophe Jaffrelot (London: Zed Books Ltd. 2004), p. 92.

${ }^{47}$ Gilles Dorronsoro, 2002). "Pakistan and the Taliban: State Policy, Religious Networks and political Connections," in Pakistan: Nationalism without a Nation? ed. Christophe Jaffrelot (London: Zed Books Ltd. 2004), pp. 161-178.

${ }^{48}$ Rashid, Taliban: The Story of the Afghan Warlords, p. 46.

${ }^{49}$ Ibid.

${ }^{50}$ US expert on South Asia, from the Woodrow Wilson International Centre for Scholars.
}

DOI: 10.9790/0837-2201022126 www.iosrjournals.org


the CIA". ${ }^{51}$ While exposing the truth further, Asif Ali Zardari, the then President of Pakistan, in an interview to NBC, on May 7, 2009, also confirmed the US role in the creation of the Taliban. Zardari said, "I think it was part of your past and our past, and the ISI and CIA created them together". 52

In the beginning the US was ambivalent towards the Taliban, and they were not resented by the US. One of the important reason of this sympathetic attitude came from American oil company UNOCAL. To US, Taliban's overtake raised the hope for UNOCAL, for laying the gas pipeline through Afghanistan. But, with the passage of time US lost interest in the Taliban government, the important reasons being their (Talibans') repressive policies particularly towards women and the strict laws with which US and the rest of the world were uncomfortable. The issue of Osama bin Laden was also the bone of contention between the US and the Taliban government. Finally, US started talking openly against the Taliban, when Hillary Clinton, in her speech about human rights at the UN said, "Even now the Taliban in Afghanistan are blocking girls from attending schools". ${ }^{53}$ They did it after a long time and out of pressure from the international community.

\section{ROLE OF SAUDI ARABIA}

Saudi Arabia also played an important role in the rise of the Taliban. Saudi Arabia's role was mostly in financing the Taliban. Actually, it was because of the US, Saudi Arabia got deeply involved in the Afghan crisis. Earlier Saudi Arabia got involved in the conflict when Soviet Union intervened militarily in Afghanistan. To fight the Soviets, US took the lead with the help of Pakistan and Saudi Arabia. The American funding to the Mujahedeen was matched by Saudi Arabia by Dollar to Dollar during the Operation Cyclone, which was directed against the Soviets. After the Soviet withdrawal from Afghanistan in 1989, US and Soviet Union both continued their funding to their favourites till 1992. From 1992 both the countries agreed to stop the funding and they got out of this conflict. But this did not make the end to the Saudis funding. When Pakistan sided towards the Taliban, Saudi Arabia had followed them and also started funding the Taliban. Saudis were actually hoping for a favourable regime in Afghanistan which will be anti-Iran, so to counter the Iranian influence, Saudi Arabia continued their support to the Taliban regime. ${ }^{54}$ The continued success of the Taliban deepened their relations with the Saudi government. With every passing day Saudi Arabia got more and more involved in Afghanistan. Prince Turki al-Faisal, the then Saudi Intelligence Chief, paid a visit to Islamabad and then to Kandahar in 1996. Many pros and cons for the future success of the Taliban were discussed. The outcome of this meeting was the arrangement of the surrender of the Jalalabad Shura. Saudis also increased their supplies to the Taliban government after this meeting. ${ }^{55}$ Saudi Arabia was also one of the three nations who recognised the Taliban regime in Afghanistan. Osama bin Laden, who was the Saudi descendent also helped the Taliban financially. With the rise of the terrorism and attacks on the US citizens around the world, Osama's continuous stay in Afghanistan became the bone of contention between Saudi Arabia and the Taliban government. After the 9/11 terrorist attacks the relations came to halt as US alleged Osama for these attacks, and Taliban was sheltering him. Saudis took the side of the US and went against the Taliban.

\section{CONCLUSION}

History bears the testimony to the grave injustices done to the unfortunate people of Afghanistan, first USSR did it with their military intervention, followed by the civil war. USSR invaded Afghanistan to strengthen Communism, then US and Pakistan involved themselves on the side of Mujahedeen to defeat the Soviets and in between the people of Afghanistan suffered the most. Finally, USSR left Afghanistan in 1989 after the much destruction. With their withdrawal the tussle for power started between different Mujahedeen factions. This tussle for power lead to civil war, which including other reasons were responsible for the rise of the Taliban. US, Pakistan and Saudi Arabia played their role directly or indirectly in the rise of this new force. Now the Taliban there in Afghanistan is a reality, they can't be avoided. If the world community is really sincere for the peace in the region, then they should be taken on board with other relevant actors. The more they will be avoided the more destruction will follow in Afghanistan and the region. There should be a consensus and compromise from every side. Even after the US intervention in Afghanistan following 9/11 terror attacks, the Taliban was of course thrown out of power, but US couldn't defeat them entirely, they have sustained the wrath of the mighty power, this should be in itself an eye opener for the world community, so to engage them is the only solution, of course only after accepting the red lines drawn in the Bonn Conference 2011.

\footnotetext{
${ }^{51}$ CIA and Pakistan created Taliban: A Revelation, Peace Research, 34, no. 2 (November 2002). Canadian Mennonite University, pp. 3334.

52 "CIA and ISI together created Taliban: Zardari," The Times of India, May 11, 2009. See also www.nbcnews.com/video/meet-the-press/30668913\#30668913 (accessed September 12, 2015).

${ }^{53}$ Coll, Ghost Wars, p. 163.

${ }^{54}$ Greg Bruno, "Saudi Arabia and the Future of Afghanistan," Council on Foreign Relations, (December 11, 2008).

${ }^{55}$ Deepak Tripathi, Breeding Ground: Afghanistan and the Origins of Islamist Terrorism, Washington D.C: Potomac Books, Inc, 2011), p. 111. 